\title{
MANAGEMENT OF ENDOCRINE DISEASE Hyperandrogenism after menopause
}

\author{
Marios C Markopoulos ${ }^{1}$, Evanthia Kassi ${ }^{2}$, Krystallenia I Alexandraki ${ }^{3}$, \\ George Mastorakos ${ }^{1}$ and Gregory Kaltsas ${ }^{3}$ \\ ${ }^{1}$ Endocrinology and Metabolism Unit, Aretaieion University Hospital, Vasilisis Sofias 76, 11528 Athens, Greece \\ ${ }^{2}$ Department of Biochemistry and ${ }^{3}$ Department of Pathophysiology, Laikon Hospital, National University of Athens, \\ Mikras Asias 75, 11527 Athens, Greece
}

Correspondence should be addressed to G Kaltsas

Email

gkaltsas@endo.gr

\begin{abstract}
Postmenopausal hyperandrogenism is a state of relative or absolute androgen excess originating from either the adrenals and/or the ovaries, clinically manifested as the appearance and/or increase in terminal hair growth or the development of symptoms/signs of virilization. In either settings, physicians need to evaluate such patients and exclude the presence of the relatively rare but potentially life-threatening underlying tumorous causes, particularly adrenal androgen-secreting tumors. It has been suggested that the rapidity of onset along with severity of symptom and the degree of androgen excess followed by relevant imaging studies may suffice to identify the source of excessive androgen secretion. However, up to date, there is no consensus regarding specific clinical and hormonal indices and/or imaging modalities required for diagnostic certainty. This is particularly relevant as the aging population is increasing and more cases of postmenopausal women with clinical/biochemical evidence of hyperandrogenism may become apparent. Furthermore, the long-term sequels of nontumorous hyperandrogenism in postmenopausal women in respect to cardiovascular morbidity and mortality still remain unsettled. This review delineates the etiology and pathophysiology of relative and absolute androgen excess in postmenopausal women. Also, it attempts to unravel distinctive clinical features along with specific hormonal cut-off levels and/or appropriate imaging modalities for the facilitation of the differential diagnosis and the identification of potential long-term sequels.
\end{abstract}

\section{Introduction}

The postmenopausal ovary remains hormonally active, secreting significant amounts of androgens and relatively fewer estrogens years after menopause (1). Although estrogen levels are reduced abruptly after menopause, androgen secretion declines gradually with aging and is maintained until later stages of life $(2,3)$. Androgen secretion in pre- and postmenopausal women depends on luteinizing hormone (LH) stimulation; after menopause the substantially increased gonadotropin levels maintain ovarian androgen secretion besides the substantial estrogen demise $(2,3)$. This imbalance between estrogens and androgens after menopause is amplified further by the evolving decrease in sex hormone-binding globulin (SHBG) concentrations and the subsequent increase in free androgen index (4). In both pre- and postmenopausal women, androgen secretion may be exacerbated further in

Invited Author's profile

Gregory Kaltsas is currently an Associate Professor in Endocrinology at the National and Kapodistrian University of Athens and Head of the Endocrine Unit of the Department of Pathophysiology. His research focuses on several aspects of neuroendocrinology and in endocrine manifestations and alterations of metabolism in a variety of medical conditions and systemic diseases.

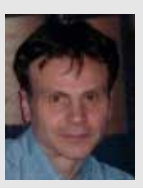


the presence of insulin resistance (IR) and hyperinsulinemia, mostly found in obese women, with insulin acting as a co-gonadotropin (5). This state of relative androgen excess is biochemically best identified with the measurement of serum testosterone levels that only rarely exceed those found in premenopause (i.e. $<40 \mathrm{ng} / \mathrm{dl}$ or $1.38 \mathrm{nmol} / \mathrm{l}$ ) (6). After menopause, even such testosterone levels may lead to the development or re-appearance of hyperandrogenic symptoms clinically evident mainly in the skin as the appearance of a few terminal hairs in the face and decrease in body and scalp hair (7). However, the development of true hirsutism, alopecia, and/or acne should not be regarded as normal, and search for preexisting or undiagnosed causes of postmenopausal hyperandrogenism should be undertaken $(7,8)$. When hirsutism is more severe and/or accompanied by symptoms/signs of virilization such as male type balding, deepening of the voice, and/or clitoromegaly (Fig. 1), a tumorous source of excessive androgen secretion originating from either the adrenals or the ovaries should be excluded $(7,8)$. Recently, cases of tumorous hyperandrogenism co-exhibiting features of erythrocytosis, thromboembolism, and sleep apnea have also been described highlighting the ability of these tumors to co-secrete other biologically active substances (9). The differential diagnosis between tumorous and nontumorous causes of hyperandrogenism is particularly important as adrenal androgen-secreting tumors can be highly malignant and potentially lifethreatening $(10,11)$. Although markedly elevated androgen levels, that define a state of absolute hyperandrogenism, are thought to be associated with tumorous hyperandrogenism, other causes of excessive androgen secretion, such as hyperthecosis and exogenous androgen administration, should also be considered $(7,8)$.

The identification of the exact cause of androgen excess in postmenopausal women may not always be evident, necessitating employment of a combination of clinical skills accompanied with appropriate laboratory indices and/or imaging techniques. However, the extent of laboratory investigation, the imaging modalities required, and the androgen cut-off levels that need to be employed for differential diagnosis are not clearly defined. In fact, there is a paucity of studies addressing these issues in postmenopausal hyperandrogenic women $(7,8,12)$.
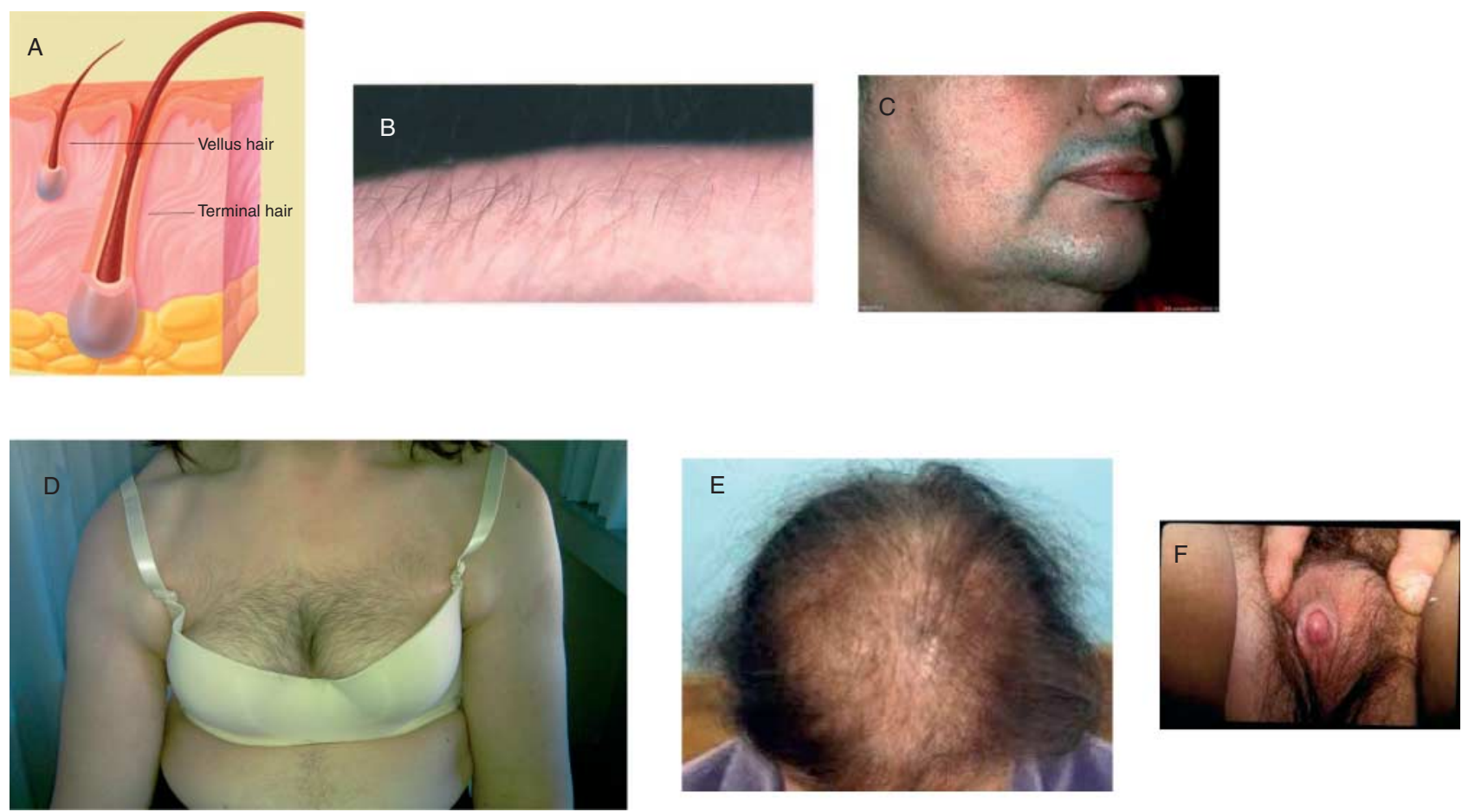

Figure 1

Signs of physiological relative hyperandrogenism ('normal' growth of terminal hair (A and B)) and of true hyperandrogenism and virilization (severe hirsutism (C and D), androgenic alopecia (E), and clitoromegaly (F)) in postmenopausal women. 


\section{Causes of hyperandrogenism after menopause}

The causes of hyperandrogenism in postmenopausal women are diverse and can be generally categorized as nontumorous or tumorous (Table 1). Although normal androgen cut-off levels have not been precisely established for menopause, it is generally accepted that they do not exceed those of premenopausal women $(6,13)$. However, androgen levels are consistently higher in patients with nontumorous hyperandrogenism compared with nonhyperandrogenic postmenopausal women $(14,15)$. Relative and occasionally absolute hyperandrogenism in postmenopause, defined as testosterone levels only modestly $>40 \mathrm{ng} / \mathrm{dl}$, is most commonly the result of nontumorous causes which usually pre-exist and may be aggravated by the physiological changes occurring in menopause (7). Tumorous hyperandrogenism is suspected when testosterone levels are $>100-140 \mathrm{ng} / \mathrm{dl}$ and is usually associated with abrupt onset and rapid evolution of symptoms or virilization (Fig. 1). However, there is a wide variation in testosterone cut-offs employed between the different studies mainly due to the relative paucity of data in postmenopausal women $(12,16,17,18)$.

Table 1 Causes of hyperandrogenism in women after menopause.

\begin{tabular}{|c|c|}
\hline \multirow{2}{*}{\multicolumn{2}{|c|}{ androgenism }} \\
\hline & \\
\hline \multicolumn{2}{|c|}{ Polycystic ovary syndrome } \\
\hline \multicolumn{2}{|c|}{$\begin{array}{l}\text { Congenital adrenal } \\
\text { hyperplasia }\end{array}$} \\
\hline \multicolumn{2}{|c|}{ Ovarian hyperthecosis } \\
\hline \multicolumn{2}{|l|}{ Obesity } \\
\hline \multicolumn{2}{|c|}{ States of insulin resistance } \\
\hline \multirow[t]{2}{*}{ Endocrinopathies } & Cushing's syndrome \\
\hline & Acromegaly \\
\hline \multirow[t]{4}{*}{ latrogenic } & Testosterone/DHEA \\
\hline & $\begin{array}{l}\text { supplementation } \\
\text { Antiepileptics (valproic acid }\end{array}$ \\
\hline & $\begin{array}{l}\text { Antieplleptics (valproic acid } \\
\text { and oxcarbazepine) }\end{array}$ \\
\hline & Danazol \\
\hline \multicolumn{2}{|c|}{ Tumorous hyperandrogenism } \\
\hline \multirow[t]{3}{*}{ Adrenal tumors } & Androgen-secreting \\
\hline & carcinomas \\
\hline & Androgen-secreting adenomas \\
\hline \multirow[t]{5}{*}{ Ovarian tumors } & $\begin{array}{l}\text { Sertoli-Leydig cell tumors } \\
\text { (androblastomas) }\end{array}$ \\
\hline & Hilus cell tumors \\
\hline & Granulosa theca cell tumors \\
\hline & $\begin{array}{l}\text { Metastatic neuroendocrine/ } \\
\text { gastrointestinal tumors }\end{array}$ \\
\hline & Cystadenomas \\
\hline
\end{tabular}

\section{Nontumorous hyperandrogenism}

\section{Polycystic ovary syndrome}

Polycystic ovary syndrome (PCOS) is the most common cause of hyperandrogenism in women of reproductive age diagnosed on the basis of specific clinical, biochemical, and/or morphological criteria (19). However, PCOS in postmenopausal women is not well defined $(19,20)$, as no robust criteria are currently available and only recently age-based criteria for the definition of PCOS have been proposed (21). Androgen excess in PCOS is mainly attributed to increased androgen production by the theca cells (22) under the stimulatory effect of $\mathrm{LH}$ and/or insulin that acts as a co-gonadotropin (5); a fraction of women with PCOS also has adrenal androgen excess, as shown by elevated DHEAS levels (23). In women with PCOS, symptoms usually start in adolescence and gradually progress during reproductive years (24), with their severity depending on the presence of IR and obesity that is also associated with an increased risk for metabolic abnormalities (25). Although in perimenopause there is an amelioration of the clinical and laboratory features of PCOS $(26,27)$, elevated androgen levels of both ovarian and adrenal origin continue to persist during early postmenopause (14) and remain elevated up to late menopause without exceeding premenopausal levels (28). Although other androgens such as androstanediol glucuronide may also be implicated particularly in the development of hirsutism, there is no data on their potential effect in postmenopausal women with PCOS (29). However, there is controversy as to whether premenopausal metabolic abnormalities found in women with PCOS persist after menopause (30) and predispose these patients to higher risk for cardiovascular disease (CVD) (31) and hormonedependent malignancies (32).

\section{Enzymatic deficiencies (congenital adrenal hyperplasia)}

Enzymatic deficiencies causing adrenal hyperplasia and excessive androgen production are mainly due to 21 -hydroxylase and rarely due to $3 \beta$-hydroxysteroid dehydrogenase and 11ß-hydroxylase deficiencies (33, 34, $35)$. Nonclassic adrenal hyperplasia (NCAH) arising from 21-hydroxylase deficiency is found in $1-10 \%$ of hyperandrogenic women, depending on ethnicity, and is associated with elevated 17-hydroxy-progesterone (17-OHP) and adrenal androgen levels (33). The symptoms/signs are usually mild and progressive, mimicking PCOS and may develop at a later stage. The prevalence of hirsutism in 
women with NCAH increases with age, and the degree of hyperandrogenism may worsen in postmenopausal women (36) in contrast to the amelioration found with aging in women with PCOS $(26,27)$. In addition, patients with adrenal hyperplasia may also have IR and hyperinsulinemia contributing further to the unfavorable metabolic profile of menopause (37). The majority of women with congenital adrenal hyperplasia (CAH) presenting in the menopausal period usually have a mild phenotype as a response to long-term treatment with glucocorticoids. However, patients with classic $\mathrm{CAH}$ inadequately treated may also present in postmenopause with symptoms/signs of hyperandrogenism, although most of such cases are diagnosed and treated at a much younger age (38).

\section{Ovarian hyperthecosis}

Ovarian hyperthecosis $(\mathrm{OH})$ is a non-neoplastic disorder mainly diagnosed in postmenopausal women mimicking the clinical manifestations and metabolic sequel of PCOS $(15,39)$. Although the precise etiology is not known, it is thought to be related to elevated postmenopausal gonadotropin levels (40). Women with $\mathrm{OH}$ typically present with a long history of slowly progressive hyperandrogenism often resulting in virilization. Their hormonal profile is characterized by markedly increased serum testosterone levels $(>150 \mathrm{ng} / \mathrm{dl})$ in the absence of other elevated androgens, accompanied with high gonadotropin levels $(39,40,41)$; ultrasound examination usually reveals bilaterally bigger than normal postmenopausal ovaries (mean size $7.7 \pm 2.3$ vs $2.3 \pm 0.01 \mathrm{ml}$ respectively) $(39,42,43)$. The diagnosis is confirmed histologically demonstrating the characteristic nests of differentiated ovarian interstitial cells into steroidogenically active luteinized stromal cells throughout the ovarian stroma (44). In the majority of patients, severe IR and hyperinsulinemia occurs, enhancing ovarian androgen production and leading to clinical manifestations such as central obesity, skin tags, and acanthosis nigricans (45). Overall, the hormonal and metabolic aberrations related to $\mathrm{OH}$ contribute significantly to an increased risk for type 2 diabetes and CVD $(39,46)$, while the extensive peripheral aromatization of androgens increases the risk for endometrial hyperplasia and carcinoma (47).

\section{Endocrinopathies}

Endocrinopathies such as Cushing's syndrome (CS) and acromegaly may also be diagnosed after menopause and cause symptoms/signs of androgen excess albeit with biochemically relative hyperandrogenism (41). Hirsutism can be found in $\sim 50 \%$ of patients with CS mainly attributed to adrenal androgen excess (48); endogenous hypercortisolism also correlates positively to free androgen levels probably due to SHBG reduction (48). In contrast to CS secondary to adrenal carcinomas, signs of hyperandrogenism are usually mild in women with the adrenocorticotropin-dependent CS and are virtually absent in women with adrenal adenomas (49). Acromegaly is a rare cause of hyperandrogenism in women, although hirsutism and less commonly acne can be found in up to $50 \%$ of the patients (50). Growth hormone (GH) hypersecretion induces a state of ovarian hyperandrogenism that along with the increased insulin-like growth factor 1 levels and concomitant hyperinsulinemia stimulate ovarian testosterone production (51). In addition, GH levels correlate negatively with SHBG levels, contributing to elevated free androgen levels (50). A number of other, albeit relatively rare, endocrinopathies usually diagnosed before menopause may also present at the postmenopausal period with symptoms and/or signs of hyperandrogenism necessitating increased awareness (29). The patients with glucocorticoid resistant states or altered glucocorticoid metabolism may be diagnosed at a later stage, as well as patients with androgen insensitivity (AI) states (29). Indeed, although the diagnosis of AI is generally made during the first decades of life in patients presenting with bilateral inguinal hernia or amenorrhea, a 70-year-old patient with complete AI has recently been described (52).

\section{latrogenic hyperandrogenism}

Iatrogenic or self-administration of androgenic drugs and supplements can induce symptoms and signs of hyperandrogenism via an increase in circulating androgen levels or an intrinsic androgenic activity of the drug. Drugs most commonly responsible for this include androgens, anabolic steroids, and antiepileptics (53). The use of testosterone or DHEA supplementation for the treatment of menopausal and androgen-deficiency-related symptoms may lead to frank hyperandrogenism. The antiepileptic drug valproic acid (VPA) has also been found to stimulate directly ovarian androgen biosynthesis in vitro (54). Epidemiological studies have shown that prolonged VPA treatment increases the risk of developing a PCOS-like clinical and biochemical phenotype (55), whereas oxcarbazepine has been associated with biochemical hyperandrogenism as well (56). 


\section{Tumorous hyperandrogenism}

Although relatively rare, androgen-secreting neoplasms originating from either the adrenals or the ovaries are potentially life-threatening causes of androgen excess, and some occur more frequently in postmenopausal women. Androgen-secreting neoplasms are usually associated with absolute hyperandrogenism (testosterone levels $>100-140 \mathrm{ng} / \mathrm{dl}$ ); this relatively broad range of testosterone cut-offs reflects the wide variation of testosterone levels in the different studies and the lack of meticulous registration of such patients $(7,8,12,17,18)$. The androgen-secreting neoplasms usually have distinct clinical features and have traditionally been associated with a rapid onset of signs and symptoms resulting in various degrees of virilization $(7,8)$.

\section{Androgen-secreting adrenal tumors}

The androgen-secreting tumors of adrenal origin have an incidence of $\sim 1-2$ cases/million population per year, affecting mostly women at perimenopause or menopause; they are usually malignant, although benign tumors have also been reported $(10,11)$. Androgen-secreting adrenal carcinomas are considered gonadotropin independent, although rare exceptions do exist (11). These tumors characteristically produce androgens (mainly testosterone and DHEAS) and many steroid precursors, either exclusively or in association with cortisol, resulting in a clinical phenotype of mixed androgen and cortisol excess. Approximately, $25 \%$ of patients present with a combination of virilization and hypercortisolism, whereas $<10 \%$ present solely with virilization $(57,58)$. The few studies that have specifically evaluated postmenopausal women $(n=9)$ with adrenal androgen-producing tumors have verified their malignant potential and prognosis depending on Weiss score and disease extent $(10,11)$. In these studies, signs of virilization were present in only a few patients, tumor size ranged between 4 and $21 \mathrm{~cm}$ (mean $11.5 \mathrm{~cm}$ ), whereas testosterone was shown to be the most consistently elevated androgen with mean levels that were 8.5 times higher than normal $(10,11)$. Although tumor size and/or testosterone levels were higher in patients with malignant tumors, these parameters could not reliably distinguish them from benign tumors as the number of patients studied was relatively small $(10,11)$.

\section{Androgen-secreting ovarian tumors}

The androgen-secreting ovarian tumors arise from the sex cord cells that surround the oocytes, but some may also originate from the stroma (59). The sex cord-stromal tumors are relative rare, comprising $5-8 \%$ of all ovarian neoplasms, and are subdivided further according to the cell of origin; less than half are androgen secreting (Table 2) $(59,60)$. The Sertoli-Leydig cell tumors (androblastomas) account for $<0.5 \%$ of all ovarian tumors, and although can occur at any age, approximately one-fourth present after menopause $(61,62)$. These tumors exhibit a variable composition of Sertoli, Leydig, and fibroblastic cells; androgenic manifestations are more common in the absence of heterologous elements and virilization is found in at least one-third of the patients $(61,62,63)$. The Sertoli-Leydig cell tumors are of relatively large size, generally unilateral and are mainly confined to the ovary at the time of diagnosis; staging is described similarly to that of other ovarian cancers (62). These tumors are rarely malignant depending also on the degree of differentiation, while some may exhibit early recurrence following surgical resection. Pure Leydig cell tumors are mostly androgen-secreting (64), whereas pure Sertoli cell tumors usually secrete estrogens (65). The hilus cell tumors

Table 2 Ovarian androgen-secreting tumors in postmenopausal women.

\begin{tabular}{|c|c|c|c|c|c|c|}
\hline Histologic type & $\begin{array}{l}\text { Age at } \\
\text { presentation } \\
\text { (years) }\end{array}$ & $\begin{array}{l}\text { Incidence } \\
\text { (of all ovarian } \\
\text { neoplasms, \%) }\end{array}$ & Hormone secretion & Symptoms & Bilaterality & $\begin{array}{l}\text { Malignant } \\
\text { potential }\end{array}$ \\
\hline $\begin{array}{l}\text { Sertoli-Leydig cell tumors } \\
\quad \text { (androblastomas) }\end{array}$ & Range, 2-75 & 0.5 & $\begin{array}{l}\text { Androgens, rarely } \\
\text { estrogens }\end{array}$ & $\begin{array}{c}\text { Virilization in about } \\
\text { one-third of cases }\end{array}$ & $\begin{array}{l}\text { Uncommon } \\
(1-2 \%)\end{array}$ & Low \\
\hline Granulosa cell tumors & $40-70$ & $2-3$ & $\begin{array}{l}\text { Estrogens, rarely } \\
\text { androgens }\end{array}$ & $\begin{array}{l}\text { Postmenopausal } \\
\text { bleeding, mass, } \\
\text { rarely virilization }\end{array}$ & About 5\% & Low \\
\hline Sertoli cell tumors & Range, 7-79 & 0.1 & $\begin{array}{l}\text { Androgens, rarely } \\
\text { estrogens }\end{array}$ & $\begin{array}{c}\text { Virilization in about } \\
30 \% \text { of patients }\end{array}$ & Rare $(1-2 \%)$ & Low \\
\hline Hilus cell tumors & $\begin{array}{l}\text { Peak at } 6 \text { th } \\
\text { decade }\end{array}$ & 0.02 & Androgens & $\begin{array}{l}\text { Hirsutism and virili- } \\
\text { zation in } 50-75 \% \\
\text { of cases }\end{array}$ & Rare & Very rare \\
\hline
\end{tabular}


are extremely rare $(0.02 \%$ of all ovarian tumors $)$ with presentation at a mean age of 58 years. They are composed of Leydig cells arising from the ovarian hilus, which exert significant steroidogenic activity leading to highly elevated testosterone levels $(59,66)$. Postmenopausal bleeding, hirsutism, and often virilization are the main clinical manifestations, whereas malignant transformation has been reported in very few cases (59). Primary granulosa cell tumors account for $2-3 \%$ of all ovarian tumors and are mostly found during the sixth decade of life (67). Although the majority are diagnosed at an early stage (stage I) and thus exhibit a good prognosis, late recurrences and dissemination necessitating systemic chemotherapy may occur. Granulosa cell tumors mainly secrete estrogens leading to postmenopausal bleeding, endometrial hyperplasia, and endometrial carcinoma; however, $\sim 10 \%$ may secrete androgens and cause virilization $(67,68)$. In addition to estradiol and testosterone, inhibin and anti-Müllerian hormone can be used as specific tumor markers for granulosa and Sertoli cell ovarian tumors $(69,70)$. It must be emphasized that the majority of ovarian androgen-secreting tumors is of relatively large size, ranging between 3 and $12 \mathrm{~cm}$ at diagnosis, and only a small minority may elude detection with current imaging modalities.

Besides sex cord-derived tumors, androgen secretion may be the result of ovarian metastases from neuroendocrine tumors, other malignancies, and serous cystadenomas that are not known to be steroidogenic. In such cases, ectopic secretion of $\beta$-hCG has been speculated to stimulate the steroidogenic cells through a paracrine mechanism (71), whereas serous cystadenomas may lead to surrounding stromal hyperplasia similarly to metastases from other malignancies that can present with the same manner (72).

\section{Diagnosis and differential diagnosis}

The diagnosis of hyperandrogenism after menopause is based on clinical suspicion, detailed history, and physical examination and is substantiated further by biochemical and morphological confirmation (Fig. 2). The onset, progression, and severity of symptoms/signs of hyperandrogenism need to be clarified. The causes of 'nontumorous hyperandrogenism', such as PCOS and NCAH, so called functional hyperandrogenism, are clinically manifested before menopause. In such cases, hirsutism and/or alopecia may even worsen during peri-menopause and early menopause (7) and are mostly associated with relative hyperandrogenism (14). The lack of premenopausal hyperandrogenic symptoms and symptom onset after menopause are not consistent with aggravation of previously present or unrecognized forms of functional hyperandrogenism (7). Clitoromegaly (clitoral size $>1.5 \times$ $2.5 \mathrm{~cm}$ ) and other signs of virilization should always direct toward $\mathrm{OH}$ or an androgen secreting neoplasm even if symptom progression is not rapid (73). However, the clinical phenotype alone cannot reliably discriminate tumorous from nontumorous causes of hyperandrogenism (12). Conversely, a florid clinical phenotype may be suggestive of an underlying endocrinopathy such as CS or acromegaly, although mild cases may be diagnosed with substantial delay $(48,50)$. When the underlying cause is CAH or NCAH basal or stimulated 17-OHP levels usually suffice to make the diagnosis (38). Very high serum testosterone (>150-200 ng/dl) and/or DHEAS (>6000 ng/ml) levels are more in favor of an androgensecreting tumor of ovarian and adrenal origin respectively, whereas testosterone appears to be the most consistently raised androgen $(17,74)$. Although similarly high testosterone levels may also be found in women with $\mathrm{OH}$, distinguishing between these two entities may not always be possible, whereas other than testosterone raised androgen levels are more in favour of a tumor. However, these cut-offs have been obtained from series that have included both pre- and postmenopausal hyperandrogenic women and their predictive value varies considerably (18). In order to improve the diagnostic accuracy of raised serum androgens, the testosterone response to dexamethasone administration has been used based on the rationale that elevated testosterone levels due to adrenal or ovarian tumors are not responsive to dexamethasone administration $(17,18)$. However, lack of suppression of testosterone levels may similarly occur in nontumorous cases, as a $>40 \%$ testosterone reduction following a formal low dose dexamethasone suppression test was found in only $88 \%$ of them (18). Although administration of gonadotropin-releasing hormone (GnRH) analog administration has been shown to normalize elevated testosterone levels in patients with hyperandrogenism of ovarian origin, this test cannot distinguish between androgen-secreting tumors and $\mathrm{OH}(75,76)$. However, the use of both these tests is not considered to be a reliable mean to delineate the cause of hyperandrogenism (8).

The presence of symptoms along with absolute biochemical hyperandrogenism requires utilization of relevant imaging modalities to exclude an androgensecreting tumor. The ovarian tumors are usually large and can be identified with transvaginal ultrasonography and/or magnetic resonance imaging (MRI). It has been 


政

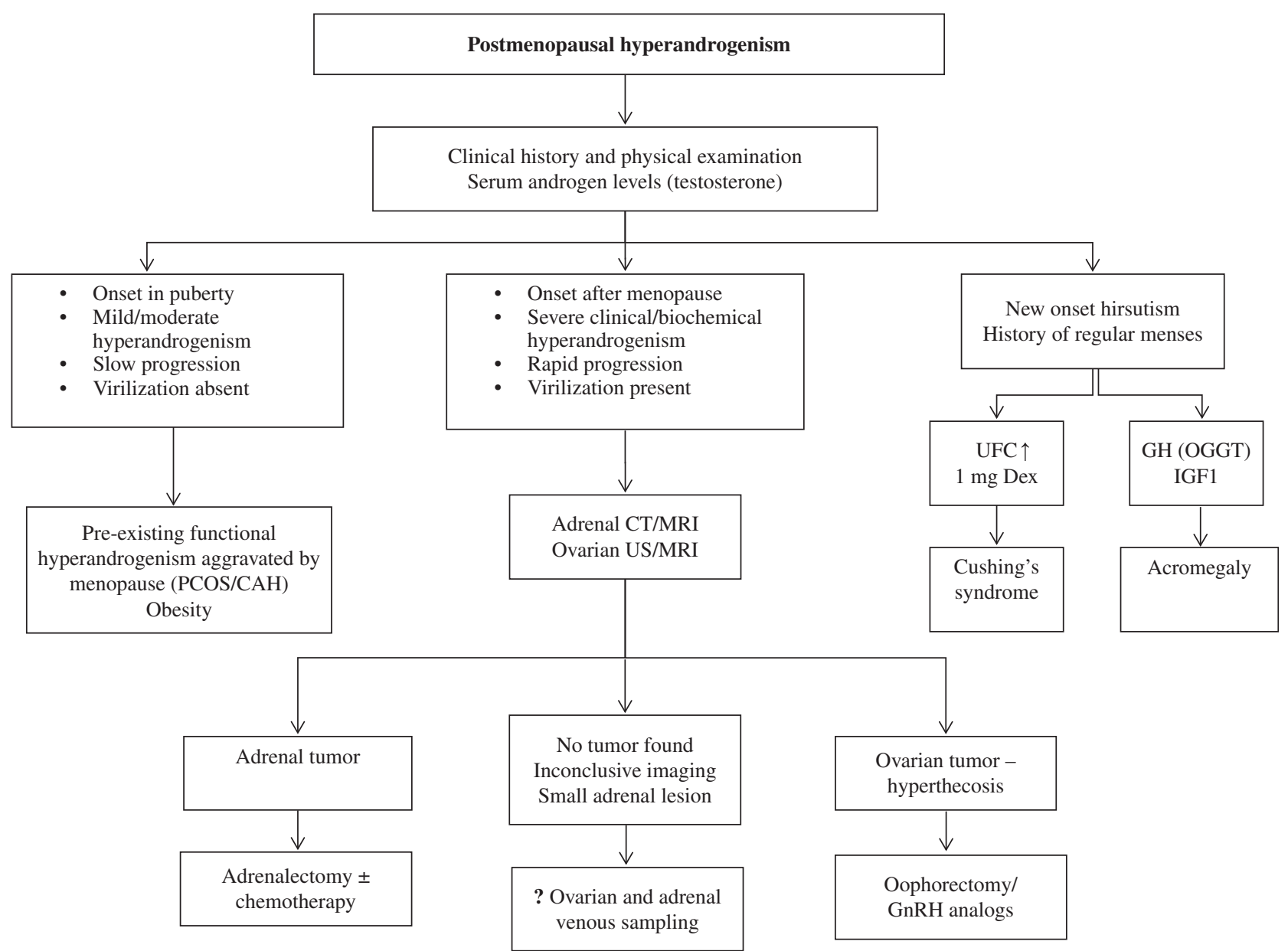

Onset in puberty

- Mild/moderate hyperandrogenism

- Slow progression

- Virilization absent

\section{Figure 2}

Diagnostic algorithm for the investigation of hyperandrogenism in women after menopause. PCOS, polycystic ovary syndrome; $\mathrm{CAH}$, congenital adrenal hyperplasia; UFC, urinary free cortisol; Dex, dexamethasone; GH, growth hormone; OGTT, oral glucose tolerance test; IGF1, insulin-like growth factor 1 . Adopted with modification from references 'Rothman MS \&

suggested that MRI may be more sensitive and specific than ultrasonography in the identification of ovarian tumors, as it has shown the highest positive and negative predictive value (78 and 100\% respectively) in the largest and most detailed study evaluating postmenopausal women with and without tumorous hyperandrogenism (12). Occasionally, some tumors may be of relatively small size and elude radiological detection (18). In such cases, asymmetry of the ovaries may be suggestive of an underlying tumor, but the chance that such tumors may be malignant is virtually zero $(12,18)$. Although adrenal tumors are less common than ovarian, they are usually of
Wierman ME. How should postmenopausal androgen excess be evaluated? Clinical Endocrinology 201175 160-164' and 'Alpanes M, Gonzalez-Casbas JM, Sanchez J, Pian H \& EscobarMorreale HF. Management of postmenopausal virilization. Journal of Clinical Endocrinology and Metabolism 201297 2584-2588'.

large size exhibiting distinct radiological features and can easily be identified with computed tomography or MRI (77). A potential pitfall is the detection of an adrenal adenoma that is found with a prevalence of up to $7 \%$ in the elderly population; however, this is usually not the cause of excessive androgen secretion (77). In such cases adrenal and ovarian venous catheterization and sampling, although tedious, may be helpful in delineating the source of androgen hypersecretion (8). However, this technique requires prompt catheterization of all four veins and should be performed in centres with additional expertise (78). 
Up to date a single multicenter study evaluating 22 postmenopausal hyperandrogenic women in whom histology was available has specifically tried to identify clinical, biochemical, and imaging features that could distinguish between tumorous $(n=10)$ and nontumorous $(n=12)$ causes (12). The signs of virilization, although most commonly encountered in patients with tumors, were also found in patients without tumors; conversely, patients with tumors presented only with hirsutism (12). Testosterone was the most commonly raised androgen and although mean testosterone levels were higher in patients with tumors, there was considerable overlap as patients with virilization and testosterone levels of $370 \mathrm{ng} / \mathrm{dl}$ had normal histology, whereas patients with tumors had testosterone levels as low as $50 \mathrm{ng} / \mathrm{dl}$; however, only two patients with tumors had testosterone levels $<100 \mathrm{ng} / \mathrm{dl}$ (12). Of interest, the immunohistochemical analysis in hyperandrogenic patients without tumors revealed an increased number of ovarian androgen-producing cells. The same authors calculated that the likelihood ratio of a patient having an androgen-secreting tumor was 8.4 and 10.8 times higher for a testosterone level $>140 \mathrm{ng} / \mathrm{dl}$ and a follicle-stimulating hormone level $<35 \mathrm{IU} / 1$ respectively (12).

\section{Treatment}

Treatment options for hyperandrogenism in postmenopausal women are based on the underlying cause and are summarized in Table 3. In cases of nontumorous hyperandrogenism of functional etiology, such as PCOS or NCAH, patients can be treated medically with antiandrogens such as cyproterone acetate, spironolactone, and flutamide (79). Additional local therapies can also be applied. Patients with classic CAH are effectively treated with hydrocortisone and this usually ameliorates the clinical phenotype; patients with NCAH may be treated similarly to PCOS, although in rare cases hydrocortisone may also be needed (38). Although the effect of metformin on steroidogenesis in postmenopausal women is not known, it may be of value in insulin-resistant hyperandrogenic women along with lifestyle modifications such as diet and regular exercise, especially in the presence of obesity (79). Iatrogenic hyperandrogenism is managed by discontinuing the medication or supplement use. In patients with underlying endocrinopathies, such as CS and acromegaly, tumor-directed treatments are employed according to published guidelines $(80,81)$. Hyperandrogenism related to $\mathrm{OH}$ can be treated either by bilateral oophorectomy or GnRH analogs; such treatment
Table 3 Treatment of hyperandrogenism of nontumorous and tumorous etiology in postmenopausal women.

\begin{tabular}{|c|c|}
\hline & Treatment \\
\hline \multicolumn{2}{|l|}{ Non tumorous etiology } \\
\hline \multirow{4}{*}{$\begin{array}{l}\text { Functional hyperandro- } \\
\text { genism (PCOS, NCAH, } \\
\text { and obesity) }\end{array}$} & Cyproterone acetate \\
\hline & \\
\hline & Local therapies (hirsutism) \\
\hline & Diet and exercise \\
\hline \multirow{2}{*}{$\begin{array}{l}\text { Ovarian hyperthecosis } \\
\text { latrogenic }\end{array}$} & Surgical resection/GNRH analogs \\
\hline & $\begin{array}{l}\text { Discontinuation of drugs/ } \\
\text { supplements }\end{array}$ \\
\hline \multicolumn{2}{|l|}{ Endocrinopathies } \\
\hline Cushing's syndrome & Surgical resection/adrenolytics \\
\hline Acromegaly & $\begin{array}{l}\text { Surgical resection/Somatostatin } \\
\text { analogs/pegvisomant }\end{array}$ \\
\hline \multicolumn{2}{|l|}{ Tumorous etiology } \\
\hline \multirow[t]{2}{*}{ Adrenal tumors } & Surgical resection (stage I/II) \\
\hline & $\begin{array}{l}\text { Adjuvant therapy - mitotane } \\
\text { (stage III/IV) }\end{array}$ \\
\hline \multirow[t]{2}{*}{ Ovarian tumors } & Oophorectomy \\
\hline & GNRH analogs \\
\hline
\end{tabular}

PCOS, polycystic ovary syndrome; NCAH, non-classic adrenal hyperplasia.

has been shown to improve symptoms and may ameliorate concomitant metabolic abnormalities $(39,40,76)$. Postmenopausal women with androgen-secreting ovarian neoplasms typically undergo surgical treatment because such tumors are diagnosed with early-stage disease; GnRH analogs can be administered when patients are not suitable candidates for surgery or when the radiological presence of a tumor has not been confirmed (76). Adrenal androgen-secreting-tumors should be treated aggressively because they present the most life-threatening androgensecreting tumor and their prognosis is directly related to the stage of the disease. Adjuvant treatment with mitotane and chemotherapy may be needed for patients with extensive disease (82).

\section{Sequels}

Androgens play a significant role in women as key regulators of cardiovascular, bone, and brain functions, and hyperandrogenism has important implications in the physical and psychological well-being of postmenopausal women. In women, CVD rates begin to escalate in the fifth decade of life with an additional increase in mortality secondary to coronary events (83). It has previously been suggested that androgen levels at the higher physiological range as well as androgen excess increase the risk for CVD in both pre- and postmenopausal women (84), and that identification of individuals at risk in premenopause may 
be crucial as such patients may confer their susceptibility to the postmenopause (85). This is particularly relevant for hyperandrogenic premenopausal women who exhibit up to $33-47 \%$ prevalence of the metabolic syndrome (MetS) and may be at increased risk for CVD in the postmenopausal state (86); however, the majority of retrospective or cross-sectional studies performed have produced conflicting results (87). A large study evaluating 104 women with self-reported history of PCOS and hyperandrogenemia showed that such patients were more often diagnosed as diabetic, obese, having the MetS and more angiographic coronary artery disease compared with those without clinical features of PCOS; in addition the cumulative 5 -year cardiovascular free survival was $78.9 \%$ in women with PCOS vs $88.7 \%$ in women without PCOS (88). However, this study was critisized due to self-reporting bias of PCOS and the fact that PCOS improves with age $(26,27)$. In addition, a subsequent study of 35 women with histologically proven PCOS who were re-evaluated after a period of 21 years showed that, although women with PCOS had a higher prevalence of hypertension and triglyceride levels than controls, the prevalence of myocardial infarction, stroke, diabetes, cancer, and mortality was similar in the two cohorts (89). Furthermore, a recent longitudinal study of 1929 women from the SWAN cohort with a follow-up period over 12 years has shown that the history of androgen excess and menstrual irregularity was not associated with worsening of the metabolic profile, thus questioning the view that concurrent hyperandrogenism and oligomenorrhea reflect cardiometabolic risk in postmenopausal women (87). Similar data regarding the lack of any effect of highly elevated androgen levels on metabolic indices, such as insulin sensitivity and body weight, are obtained following normalization of androgen levels after surgical oophorectomy in patients with ovarian androgen-secreting tumors (90). Although the issue is still not settled, it seems prudent to suggest that the higher prevalence of adverse cardiometabolic risk factors in hyperandrogenic pre- and postmenopausal women does not seem to increase the prevalence of CVD and/or overall mortality $(87,89,90,91)$.

After menopause, androgen levels are positively associated with an increased breast cancer risk and other gynecological malignancies $(32,92,93,94)$. The positive correlation of elevated endogenous androgen (testosterone and DHEAS) levels with postmenopausal breast cancer is more evident in estrogen receptor-positive breast tumors $(95,96)$. In contrast, higher circulating levels of bioavailable testosterone have been associated with a lower risk for estrogen receptor-negative breast tumors in postmenopausal women in some (97), but not all studies (98). A recent meta-analysis of all observational studies examining the risk of gynecological cancers in PCOS has concluded that women of all ages have an increased risk for endometrial, ovarian, and breast cancers, but the risk is significantly increased only for endometrial carcinoma; however, in patients younger than 54 years there is also a significant increased risk for ovarian cancer (32).

In general, androgen levels in women are associated positively with increased bone mass density (BMD) $(99,100)$; however, after menopause this protective role of androgen to bone loss is less clear. In fact, free androgen levels are positively associated with BMD in women aged between 55 and 85 years (101), while the relative risk and incidence of hip fractures are higher in postmenopausal women with circulating free testosterone levels lower than normal range $(102,103)$. However, although in hyperandrogenic premenopausal women with PCOS, BMD correlates positively to androgen levels and total bone mass (104), this association does not seem to be sustained after menopause as hyperandrogenic postmenopausal women with PCOS have similar BMD as compared with normal postmenopausal women (105).

The clinical implications of androgen levels in brain function and mood of postmenopausal women have been more extensively studied in androgen insufficiency states, where a negative association with cognition, mood, motivation, and general sense of well-being has been found $(106,107)$. It seems that androgens exhibit a promoting effect on behavior and mood, whereas in elderly women, free testosterone levels correlate inversely to symptoms of depression (108). Physical and cognitive function seem to be improved in postmenopausal women with elevated circulating testosterone levels $(107,109,110)$.

\section{Conclusion}

Hyperandrogenism after menopause is a rare condition that needs careful evaluation in order not to misdiagnose an underlying androgen-secreting tumor. Clinical phenotype and symptom onset do not reliably permit discrimination between tumorous and nontumorous causes, but may help to identify other endocrinopathies; however, in the presence of virilization an underlying tumorous cause needs to be excluded. Measurement of total testosterone levels as the sole androgen along with current imaging modalities may help to avoid a life-threatening adrenal tumor and identify the majority of ovarian androgensecreting tumors, whereas adrenal and ovarian venous 
catheterization and sampling should be employed only in selected cases. Although a highly sensitive and specific testosterone cut-off level to discriminate tumorous from nontumorous causes cannot be reliably defined, testosterone levels $>100 \mathrm{ng} / \mathrm{dl}$, and particularly $140 \mathrm{ng} / \mathrm{dl}$, are more in favor of an androgen-secreting tumor or $\mathrm{OH}$. Surgery remains the main curative treatment, particularly for adrenal androgen-secreting tumors and may be substantiated with adjuvant therapy, whereas GNRH analogs can be used in patients with ovarian hyperandrogenism with no obvious tumors at imaging and/or unfit for surgery. There is currently no evidence that women with functional postmenopausal hyperandrogenism are at higher risk for CVD than women without hyperandrogenism, but this issue needs to be further evaluated.

\section{Declaration of interest}

The authors declare that there is no conflict of interest that could be perceived as prejudicing the impartiality of the review.

\section{Funding}

This review did not receive any specific grant from any funding agency in the public, commercial or not-for-profit sector.

\section{References}

1 Fogle RH, Stanczyk FZ, Zhang X \& Paulson RJ. Ovarian androgen production in postmenopausal women. Journal of Clinical Endocrinology and Metabolism 200792 3040-3043. (doi:10.1210/jc.20070581)

2 Sluijmer AV, Heineman MJ, De Jong FH \& Evers JL. Endocrine activity of the postmenopausal ovary: the effects of pituitary down-regulation and oophorectomy. Journal of Clinical Endocrinology and Metabolism 199580 2163-2167. (doi:10.1210/jcem.80.7.7608272)

3 Adashi EY. The climacteric ovary as a functional gonadotropin-driven androgen-producing gland. Fertility and Sterility 199462 20-27.

4 Gershagen S, Doeberl A, Jeppsson S \& Rannevik G. Decreasing serum levels of sex hormone-binding globulin around the menopause and temporary relation to changing levels of ovarian steroids, as demonstrated in a longitudinal study. Fertility and Sterility $1989 \mathbf{5 1}$ 616-621.

5 Barbieri RL, Smith S \& Ryan KJ. The role of hyperinsulinemia in the pathogenesis of ovarian hyperandrogenism. Fertility and Sterility 1988 50 197-212.

6 Haring R, Hannemann A, John U, Radke D, Nauck M, Wallaschofski H, Owen L, Adaway J, Keevil BG \& Brabant G. Age-specific reference ranges for serum testosterone and androstenedione concentrations in women measured by liquid chromatography-tandem mass spectrometry. Journal of Clinical Endocrinology and Metabolism 201297 408-415. (doi:10.1210/jc.2011-2134)

7 Rothman MS \& Wierman ME. How should postmenopausal androgen excess be evaluated? Clinical Endocrinology 201175 160-164. (doi:10.1111/j.1365-2265.2011.04040.x)

8 Alpanes M, Gonzalez-Casbas JM, Sanchez J, Pian H \& EscobarMorreale HF. Management of postmenopausal virilization. Journal of Clinical Endocrinology and Metabolism 201297 2584-2588. (doi:10.1210/jc.2012-1683)
9 Kozan P, Chalasani S, Handelsman DJ, Pike AH \& Crawford BA. A Leydig cell tumor of the ovary resulting in extreme hyperandrogenism, erythrocytosis, and recurrent pulmonary embolism. Journal of Clinical Endocrinology and Metabolism 201499 12-17. (doi:10.1210/jc.2013-3108)

10 Cordera F, Grant C, van Heerden J, Thompson G \& Young W. Androgen-secreting adrenal tumors. Surgery 2003134 874-880; (discussion 880). (doi:10.1016/S0039-6060(03)00410-0)

11 Moreno S, Montoya G, Armstrong J, Leteurtre E, Aubert S, Vantyghem MC, Dewailly D, Wemeau JL \& Proye C. Profile and outcome of pure androgen-secreting adrenal tumors in women: experience of 21 cases. Surgery 2004136 1192-1198. (doi:10.1016/j. surg.2004.06.046)

12 Sarfati J, Bachelot A, Coussieu C, Meduri G, Touraine P \& Study Group Hyperandrogenism in Postmenopausal Women. Impact of clinical, hormonal, radiological, and immunohistochemical studies on the diagnosis of postmenopausal hyperandrogenism. European Journal of Endocrinology 2011165 779-788. (doi:10.1530/EJE-11-0542)

13 Elmlinger MW, Kuhnel W, Wormstall H \& Doller PC. Reference intervals for testosterone, androstenedione and SHBG levels in healthy females and males from birth until old age. Clinical Laboratory $200551625-632$.

14 Markopoulos MC, Rizos D, Valsamakis G, Deligeoroglou E, Grigoriou O, Chrousos GP, Creatsas G \& Mastorakos G. Hyperandrogenism in women with polycystic ovary syndrome persists after menopause. Journal of Clinical Endocrinology and Metabolism 201196 623-631. (doi:10.1210/jc.2010-0130)

15 Goldman JM \& Kapadia LJ. Virilization in a postmenopausal woman due to ovarian stromal hyperthecosis. Postgraduate Medical Journal 199167 304-306. (doi:10.1136/pgmj.67.785.304)

16 Friedman CI, Schmidt GE, Kim MH \& Powell J. Serum testosterone concentrations in the evaluation of androgen-producing tumors. American Journal of Obstetrics and Gynecology 1985153 44-49. (doi:10.1016/0002-9378(85)90587-3)

17 Derksen J, Nagesser SK, Meinders AE, Haak HR \& van de Velde CJ. Identification of virilizing adrenal tumors in hirsute women. New England Journal of Medicine 1994331 968-973. (doi:10.1056/ NEJM199410133311502)

18 Kaltsas GA, Isidori AM, Kola BP, Skelly RH, Chew SL, Jenkins PJ, Monson JP, Grossman AB \& Besser GM. The value of the low-dose dexamethasone suppression test in the differential diagnosis of hyperandrogenism in women. Journal of Clinical Endocrinology and Metabolism 200388 2634-2643. (doi:10.1210/jc.2002-020922)

19 Legro RS, Arslanian SA, Ehrmann DA, Hoeger KM, Murad MH, Pasquali R, Welt CK \& Endocrine S. Diagnosis and treatment of polycystic ovary syndrome: an Endocrine Society clinical practice guideline. Journal of Clinical Endocrinology and Metabolism 201398 4565-4592. (doi:10.1210/jc.2013-2350)

20 Shah D \& Bansal S. Polycystic ovaries - beyond menopause. Climacteric 201417 109-115. (doi:10.3109/13697137.2013.828687)

21 Alsamarai S, Adams JM, Murphy MK, Post MD, Hayden DL, Hall JE \& Welt CK. Criteria for polycystic ovarian morphology in polycystic ovary syndrome as a function of age. Journal of Clinical Endocrinology and Metabolism 200994 4961-4970. (doi:10.1210/jc.2009-0839)

22 Gilling-Smith C, Willis DS, Beard RW \& Franks S. Hypersecretion of androstenedione by isolated thecal cells from polycystic ovaries. Journal of Clinical Endocrinology and Metabolism 199479 1158-1165. (doi:10.1210/jcem.79.4.7962289)

23 Kumar A, Woods KS, Bartolucci AA \& Azziz R. Prevalence of adrenal androgen excess in patients with the polycystic ovary syndrome (PCOS). Clinical Endocrinology 200562 644-649. (doi:10.1111/j.13652265.2005.02256.x)

24 Pasquali R \& Gambineri A. Polycystic ovary syndrome: a multifaceted disease from adolescence to adult age. Annals of the New York Academy of Sciences 20061092 158-174. (doi:10.1196/annals.1365.014) 
25 Legro RS, Kunselman AR, Dodson WC \& Dunaif A. Prevalence and predictors of risk for type 2 diabetes mellitus and impaired glucose tolerance in polycystic ovary syndrome: a prospective, controlled study in 254 affected women. Journal of Clinical Endocrinology and Metabolism 199984 165-169. (doi:10.1210/jcem.84.1.5393)

26 Elting MW, Korsen TJ, Rekers-Mombarg LT \& Schoemaker J. Women with polycystic ovary syndrome gain regular menstrual cycles when ageing. Human Reproduction 200015 24-28. (doi:10.1093/humrep/ 15.1.24)

27 Winters SJ, Talbott E, Guzick DS, Zborowski J \& McHugh KP. Serum testosterone levels decrease in middle age in women with the polycystic ovary syndrome. Fertility and Sterility 200073 724-729. (doi:10.1016/S0015-0282(99)00641-X)

28 Schmidt J, Brannstrom M, Landin-Wilhelmsen K \& Dahlgren E. Reproductive hormone levels and anthropometry in postmenopausal women with polycystic ovary syndrome (PCOS): a 21-year follow-up study of women diagnosed with PCOS around 50 years ago and their age-matched controls. Journal of Clinical Endocrinology and Metabolism 201196 2178-2185. (doi:10.1210/jc.2010-2959)

29 Kaltsas GA, Isidori AM, Besser GM \& Grossman AB. Secondary forms of polycystic ovary syndrome. Trends in Endocrinology and Metabolism 200415 204-210. (doi:10.1016/j.tem.2004.05.009)

30 Markopoulos MC, Valsamakis G, Kouskouni E, Boutsiadis A, Papassotiriou I, Creatsas G \& Mastorakos G. Study of carbohydrate metabolism indices and adipocytokine profile and their relationship with androgens in polycystic ovary syndrome after menopause. European Journal of Endocrinology 2013168 83-90. (doi:10.1530/EJE-12-0550)

31 Wild RA, Carmina E, Diamanti-Kandarakis E, Dokras A, Escobar-Morreale HF, Futterweit W, Lobo R, Norman RJ, Talbott E \& Dumesic DA. Assessment of cardiovascular risk and prevention of cardiovascular disease in women with the polycystic ovary syndrome: a consensus statement by the Androgen Excess and Polycystic Ovary Syndrome (AE-PCOS) Society. Journal of Clinical Endocrinology and Metabolism 201095 2038-2049. (doi:10.1210/jc.2009-2724)

32 Barry JA, Azizia MM \& Hardiman PJ. Risk of endometrial, ovarian and breast cancer in women with polycystic ovary syndrome: a systematic review and meta-analysis. Human Reproduction Update 201420 748-758. (doi:10.1093/humupd/dmu012)

33 Azziz R, Sanchez LA, Knochenhauer ES, Moran C, Lazenby J, Stephens KC, Taylor K \& Boots LR. Androgen excess in women: experience with over 1000 consecutive patients. Journal of Clinical Endocrinology and Metabolism 200489 453-462. (doi:10.1210/ jc.2003-031122)

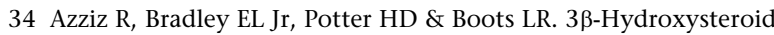
dehydrogenase deficiency in hyperandrogenism. American Journal of Obstetrics and Gynecology 1993168 889-895. (doi:10.1016/S00029378(12)90840-6)

35 Azziz R, Boots LR, Parker CR Jr, Bradley E Jr \& Zacur HA. $11 \beta$-Hydroxylase deficiency in hyperandrogenism. Fertility and Sterility 199155 733-741.

36 Moran C, Azziz R, Carmina E, Dewailly D, Fruzzetti F, Ibanez L, Knochenhauer ES, Marcondes JA, Mendonca BB, Pignatelli D et al. 21-Hydroxylase-deficient nonclassic adrenal hyperplasia is a progressive disorder: a multicenter study. American Journal of Obstetrics and Gynecology 2000183 1468-1474. (doi:10.1067/mob.2000.108020)

37 Speiser PW, Serrat J, New MI \& Gertner JM. Insulin insensitivity in adrenal hyperplasia due to nonclassical steroid 21-hydroxylase deficiency. Journal of Clinical Endocrinology and Metabolism 199275 1421-1424. (doi:10.1210/jcem.75.6.1464643)

38 Speiser PW, Azziz R, Baskin LS, Ghizzoni L, Hensle TW, Merke DP, Meyer-Bahlburg HF, Miller WL, Montori VM, Oberfield SE et al. Congenital adrenal hyperplasia due to steroid 21-hydroxylase deficiency: an Endocrine Society clinical practice guideline. Journal of Clinical Endocrinology and Metabolism 201095 4133-4160. (doi:10.1210/jc.2009-2631)
39 Barth JH, Jenkins M \& Belchetz PE. Ovarian hyperthecosis, diabetes and hirsuties in post-menopausal women. Clinical Endocrinology 1997 46 123-128. (doi:10.1046/j.1365-2265.1997.1050916.x)

40 Krug E \& Berga SL. Postmenopausal hyperthecosis: functional dysregulation of androgenesis in climacteric ovary. Obstetrics and Gynecology 200299 893-897. (doi:10.1016/S0029-7844(01)01588-5)

41 O'Driscoll JB, Mamtora H, Higginson J, Pollock A, Kane J \& Anderson DC. A prospective study of the prevalence of clear-cut endocrine disorders and polycystic ovaries in 350 patients presenting with hirsutism or androgenic alopecia. Clinical Endocrinology 199441 231-236. (doi:10.1111/j.1365-2265.1994.tb02535.x)

42 Rousset P, Gompel A, Christin-Maitre S, Pugeat M, Hugol D, Ghossain MA \& Buy JN. Ovarian hyperthecosis on grayscale and color Doppler ultrasound. Ultrasound in Obstetrics \& Gynecology 200832 694-699. (doi:10.1002/uog.6131)

43 Goswamy RK, Campbell S, Royston JP, Bhan V, Battersby RH, Hall VJ, Whitehead MI \& Collins WP. Ovarian size in postmenopausal women. British Journal of Obstetrics and Gynaecology 198895 795-801. (doi:10.1111/j.1471-0528.1988.tb06554.x)

44 Brown DL, Henrichsen TL, Clayton AC, Hudson SB, Coddington CC III \& Vella A. Ovarian stromal hyperthecosis: sonographic features and histologic associations. Journal of Ultrasound in Medicine 200928 587-593.

45 Nagamani M, Van Dinh T \& Kelver ME. Hyperinsulinemia in hyperthecosis of the ovaries. American Journal of Obstetrics and Gynecology 1986154 384-389. (doi:10.1016/0002-9378(86)90676-9)

46 Kim Y, Marjoniemi VM, Diamond T, Lim A, Davis G \& Murrell D. Androgenetic alopecia in a postmenopausal woman as a result of ovarian hyperthecosis. Australasian Journal of Dermatology $2003 \mathbf{4 4}$ 62-66. (doi:10.1046/j.1440-0960.2003.00640.x)

47 Nagamani M, Hannigan EV, Dinh TV \& Stuart CA. Hyperinsulinemia and stromal luteinization of the ovaries in postmenopausal women with endometrial cancer. Journal of Clinical Endocrinology and Metabolism 198867 144-148. (doi:10.1210/jcem-67-1-144)

48 Kaltsas GA, Korbonits M, Isidori AM, Webb JA, Trainer PJ, Monson JP, Besser GM \& Grossman AB. How common are polycystic ovaries and the polycystic ovarian syndrome in women with Cushing's syndrome? Clinical Endocrinology 200053 493-500. (doi:10.1046/ j.1365-2265.2000.01117.x)

49 Bertagna C \& Orth DN. Clinical and laboratory findings and results of therapy in 58 patients with adrenocortical tumors admitted to a single medical center (1951 to 1978). American Journal of Medicine 198171 855-875. (doi:10.1016/0002-9343(81)90384-3)

50 Kaltsas GA, Mukherjee JJ, Jenkins PJ, Satta MA, Islam N, Monson JP, Besser GM \& Grossman AB. Menstrual irregularity in women with acromegaly. Journal of Clinical Endocrinology and Metabolism 199984 2731-2735. (doi:10.1210/jcem.84.8.5858)

51 Kaltsas GA, Androulakis II, Tziveriotis K, Papadogias D, Tsikini A, Makras P, Dimitriou K, Stathopoulou A \& Piaditis G. Polycystic ovaries and the polycystic ovary syndrome phenotype in women with active acromegaly. Clinical Endocrinology 200767 917-922. (doi:10.1111/ j.1365-2265.2007.02987.x)

52 Arslan Y, Altintoprak F, Ozkan OV, Yalkin O, Gunduz Y \& Kahyaoglu Z. Androgen insensitivity syndrome diagnosed in an elderly patient during a strangulated inguinal hernia repair. International Journal of Surgery Case Reports 20134 1124-1126. (doi:10.1016/j.ijscr.2013.09.009)

53 Martin KA, Chang RJ, Ehrmann DA, Ibanez L, Lobo RA, Rosenfield RL, Shapiro J, Montori VM \& Swiglo BA. Evaluation and treatment of hirsutism in premenopausal women: an Endocrine Society clinical practice guideline. Journal of Clinical Endocrinology and Metabolism 200893 1105-1120. (doi:10.1210/jc.2007-2437)

54 Nelson-DeGrave VL, Wickenheisser JK, Cockrell JE, Wood JR, Legro RS, Strauss JF III \& McAllister JM. Valproate potentiates androgen biosynthesis in human ovarian theca cells. Endocrinology 2004145 799-808. (doi:10.1210/en.2003-0940) 
55 Hu X, Wang J, Dong W, Fang Q, Hu L \& Liu C. A meta-analysis of polycystic ovary syndrome in women taking valproate for epilepsy. Epilepsy Research 201197 73-82. (doi:10.1016/j.eplepsyres.2011.07.006)

56 Lofgren E, Tapanainen JS, Koivunen R, Pakarinen A \& Isojarvi JI. Effects of carbamazepine and oxcarbazepine on the reproductive endocrine function in women with epilepsy. Epilepsia 200647 1441-1446. (doi:10.1111/j.1528-1167.2006.00506.x)

$57 \mathrm{Ng}$ L \& Libertino JM. Adrenocortical carcinoma: diagnosis, evaluation and treatment. Journal of Urology 2003169 5-11. (doi:10.1016/S00225347(05)64023-2)

58 Tritos NA, Cushing GW, Heatley G \& Libertino JA. Clinical features and prognostic factors associated with adrenocortical carcinoma: Lahey Clinic Medical Center experience. American Surgeon 200066 73-79.

59 Olt G \& Mortel R. Hormone-producing tumors of the ovary. EndocrineRelated Cancer 19974 447-457. (doi:10.1677/erc.0.0040447)

60 Quirk JT \& Natarajan N. Ovarian cancer incidence in the United States, 1992-1999. Gynecologic Oncology 200597 519-523. (doi:10.1016/ j.ygyno.2005.02.007)

61 Young RH \& Scully RE. Ovarian Sertoli-Leydig cell tumors. A clinicopathological analysis of 207 cases. American Journal of Surgical Pathology 19859 543-569. (doi:10.1097/00000478-198508000-00001)

62 Gui T, Cao D, Shen K, Yang J, Zhang Y, Yu Q, Wan X, Xiang Y, Xiao Y \& Guo L. A clinicopathological analysis of 40 cases of ovarian Sertoli-Leydig cell tumors. Gynecologic Oncology 2012127 384-389. (doi:10.1016/j.ygyno.2012.07.114)

63 Sigismondi C, Gadducci A, Lorusso D, Candiani M, Breda E, Raspagliesi F, Cormio G, Marinaccio M \& Mangili G. Ovarian SertoliLeydig cell tumors. a retrospective MITO study. Gynecologic Oncology 2012125 673-676. (doi:10.1016/j.ygyno.2012.03.024)

64 Takeuchi S, Ishihara N, Ohbayashi C, Itoh H \& Maruo T. Stromal Leydig cell tumor of the ovary. Case report and literature review. International Journal of Gynecological Pathology 199918 178-182. (doi:10.1097/00004347-199904000-00014)

65 Oliva E, Alvarez T \& Young RH. Sertoli cell tumors of the ovary: a clinicopathologic and immunohistochemical study of 54 cases. American Journal of Surgical Pathology 200529 143-156. (doi:10.1097/ 01.pas.0000149692.21205.9c)

66 Dunnihoo DR, Grieme DL \& Woolf RB. Hilar-cell tumors of the ovary. Report of 2 new cases and a review of the world literature. Obstetrics and Gynecology 196627 703-713.

67 Sekkate S, Kairouani M, Serji B, Tazi A, Mrabti H, Boutayeb S \& Errihani H. Ovarian granulosa cell tumors: a retrospective study of 27 cases and a review of the literature. World Journal of Surgical Oncology 201311 142. (doi:10.1186/1477-7819-11-142)

68 Nakashima N, Young RH \& Scully RE. Androgenic granulosa cell tumors of the ovary. A clinicopathologic analysis of 17 cases and review of the literature. Archives of Pathology \& Laboratory Medicine 1984108 786-791.

69 Healy DL, Burger HG, Mamers P, Jobling T, Bangah M, Quinn M, Grant P, Day AJ, Rome R \& Campbell JJ. Elevated serum inhibin concentrations in postmenopausal women with ovarian tumors. New England Journal of Medicine 1993329 1539-1542. (doi:10.1056/ NEJM199311183292104)

70 Rey R, Sabourin JC, Venara M, Long WQ, Jaubert F, Zeller WP, Duvillard P, Chemes H \& Bidart JM. Anti-Müllerian hormone is a specific marker of Sertoli- and granulosa-cell origin in gonadal tumors. Human Pathology 200031 1202-1208. (doi:10.1053/hupa.2000.18498)

71 Bachelot A, Meduri G, Baudin E, Kuttenn F \& Touraine P. Hyperandrogenism in a postmenopausal woman presenting with a metastatic ileum endocrine tumor. Fertility and Sterility $2004 \mathbf{8 1}$ 675-678. (doi:10.1016/j.fertnstert.2003.07.040)

72 Heinonen PK. Androgen production by epithelial ovarian tumours in post-menopausal women. Maturitas 199113 117-122. (doi:10.1016/ 0378-5122(91)90094-7)

73 Dennedy MC, Smith D, O'Shea D \& McKenna TJ. Investigation of patients with atypical or severe hyperandrogenaemia including androgen-secreting ovarian teratoma. European Journal of Endocrinology 2010162 213-220. (doi:10.1530/EJE-09-0576)

74 Azziz R, Carmina E, Dewailly D, Diamanti-Kandarakis E, Escobar-Morreale HF, Futterweit W, Janssen OE, Legro RS, Norman RJ, Taylor AE et al. The Androgen Excess and PCOS Society criteria for the polycystic ovary syndrome: the complete task force report. Fertility and Sterility 200991 456-488. (doi:10.1016/j.fertnstert.2008.06.035)

75 Pascale MM, Pugeat M, Roberts M, Rousset H, Dechaud H, DutrieuxBerger N \& Tourniaire J. Androgen suppressive effect of GnRH agonist in ovarian hyperthecosis and virilizing tumours. Clinical Endocrinology 199441 571-576. (doi:10.1111/j.1365-2265.1994.tb01820.x)

76 Vollaard ES, van Beek AP, Verburg FA, Roos A \& Land JA. Gonadotropin-releasing hormone agonist treatment in postmenopausal women with hyperandrogenism of ovarian origin. Journal of Clinical Endocrinology and Metabolism 201196 1197-1201. (doi:10.1210/jc.2010-1991)

77 Young WF Jr. Clinical practice. The incidentally discovered adrenal mass. New England Journal of Medicine 2007356 601-610. (doi:10.1056/NEJMcp065470)

78 Kaltsas GA, Mukherjee JJ, Kola B, Isidori AM, Hanson JA, Dacie JE, Reznek R, Monson JP \& Grossman AB. Is ovarian and adrenal venous catheterization and sampling helpful in the investigation of hyperandrogenic women? Clinical Endocrinology 200359 34-43. (doi:10.1046/j.1365-2265.2003.01792.x)

79 Pasquali R \& Gambineri A. Therapy in endocrine disease: treatment of hirsutism in the polycystic ovary syndrome. European Journal of Endocrinology 2014170 R75-R90. (doi:10.1530/EJE-13-0585)

80 Biller BM, Grossman AB, Stewart PM, Melmed S, Bertagna X, Bertherat J, Buchfelder M, Colao A, Hermus AR, Hofland LJ et al. Treatment of adrenocorticotropin-dependent Cushing's syndrome: a consensus statement. Journal of Clinical Endocrinology and Metabolism 200893 2454-2462. (doi:10.1210/jc.2007-2734)

81 Katznelson L, Atkinson JL, Cook DM, Ezzat SZ, Hamrahian AH, Miller KK \& American Association of Clinical E . American Association of Clinical Endocrinologists medical guidelines for clinical practice for the diagnosis and treatment of acromegaly - 2011 update. Endocrine Practice 201117 (Suppl 4) 1-44. (doi:10.4158/EP.17.S4.1)

82 Fassnacht M, Terzolo M, Allolio B, Baudin E, Haak H, Berruti A, Welin S, Schade-Brittinger C, Lacroix A, Jarzab B et al. Combination chemotherapy in advanced adrenocortical carcinoma. New England Journal of Medicine 2012366 2189-2197. (doi:10.1056/ NEJMoa1200966)

83 Ford ES \& Capewell S. Coronary heart disease mortality among young adults in the U.S. from 1980 through 2002: concealed leveling of mortality rates. Journal of the American College of Cardiology $2007 \mathbf{5 0}$ 2128-2132. (doi:10.1016/j.jacc.2007.05.056)

$84 \mathrm{Wu}$ FC \& von Eckardstein A. Androgens and coronary artery disease. Endocrine Reviews 200324 183-217. (doi:10.1210/er.2001-0025)

85 Mosca L, Benjamin EJ, Berra K, Bezanson JL, Dolor RJ, Lloyd-Jones DM, Newby LK, Pina IL, Roger VL, Shaw LJ et al. Effectiveness-based guidelines for the prevention of cardiovascular disease in women 2011 update: a guideline from the American Heart Association. Journal of the American College of Cardiology 201157 1404-1423. (doi:10.1016/j.jacc.2011.02.005)

86 Ehrmann DA, Liljenquist DR, Kasza K, Azziz R, Legro RS \& Ghazzi MN. Prevalence and predictors of the metabolic syndrome in women with polycystic ovary syndrome. Journal of Clinical Endocrinology and Metabolism 200691 48-53. (doi:10.1210/jc.2005-1329)

87 Polotsky AJ, Allshouse AA, Crawford SL, Harlow SD, Khalil N, Kazlauskaite R, Santoro N \& Legro RS. Hyperandrogenic oligomenorrhea and metabolic risks across menopausal transition. Journal of Clinical Endocrinology and Metabolism 201499 1-8. (doi:10.1210/ jc.2013-4170)

88 Shaw LJ, Bairey Merz CN, Azziz R, Stanczyk FZ, Sopko G, Braunstein GD, Kelsey SF, Kip KE, Cooper-Dehoff RM, Johnson BD et al. Postmenopausal women with a history of irregular menses 
and elevated androgen measurements at high risk for worsening cardiovascular event-free survival: results from the National Institutes of Health - National Heart, Lung, and Blood Institute sponsored Women's Ischemia Syndrome Evaluation. Journal of Clinical Endocrinology and Metabolism 200893 1276-1284. (doi:10.1210/jc.2007-0425)

89 Schmidt J, Landin-Wilhelmsen K, Brannstrom M \& Dahlgren E. Cardiovascular disease and risk factors in PCOS women of postmenopausal age: a 21-year controlled follow-up study. Journal of Clinical Endocrinology and Metabolism 201196 3794-3803. (doi:10.1210/jc.2011-1677)

90 Pelusi C, Forlani G, Zanotti L, Gambineri A \& Pasquali R. No metabolic impact of surgical normalization of hyperandrogenism in postmenopausal women with ovarian androgen-secreting tumours. Clinical Endocrinology 201378 533-538. (doi:10.1111/j.1365-2265.2012. 04438.x)

91 Pierpoint T, McKeigue PM, Isaacs AJ, Wild SH \& Jacobs HS. Mortality of women with polycystic ovary syndrome at long-term follow-up. Journal of Clinical Epidemiology 199851 581-586. (doi:10.1016/S08954356(98)00035-3)

92 Missmer SA, Eliassen AH, Barbieri RL \& Hankinson SE. Endogenous estrogen, androgen, and progesterone concentrations and breast cancer risk among postmenopausal women. Journal of the National Cancer Institute 200496 1856-1865. (doi:10.1093/jnci/djh336)

93 Kaaks R, Rinaldi S, Key TJ, Berrino F, Peeters PH, Biessy C, Dossus L, Lukanova A, Bingham S, Khaw KT et al. Postmenopausal serum androgens, oestrogens and breast cancer risk: the European prospective investigation into cancer and nutrition. Endocrine-Related Cancer 200512 1071-1082. (doi:10.1677/erc.1.01038)

94 Endogenous H, Breast Cancer Collaborative G, Key TJ, Appleby PN, Reeves GK, Roddam AW, Helzlsouer KJ, Alberg AJ, Rollison DE, Dorgan JF et al. Circulating sex hormones and breast cancer risk factors in postmenopausal women: reanalysis of 13 studies. British Journal of Cancer 2011105 709-722. (doi:10.1038/bjc.2011.254)

95 Tamimi RM, Byrne C, Colditz GA \& Hankinson SE. Endogenous hormone levels, mammographic density, and subsequent risk of breast cancer in postmenopausal women. Journal of the National Cancer Institute 200799 1178-1187. (doi:10.1093/jnci/djm062)

96 Key T, Appleby P, Barnes I, Reeves G, Endogenous H \& Breast Cancer Collaborative G. Endogenous sex hormones and breast cancer in postmenopausal women: reanalysis of nine prospective studies. Journal of the National Cancer Institute 200294 606-616. (doi:10.1093/ jnci/94.8.606)

97 Farhat GN, Cummings SR, Chlebowski RT, Parimi N, Cauley JA, Rohan TE, Huang AJ, Vitolins M, Hubbell FA, Manson JE et al. Sex hormone levels and risks of estrogen receptor-negative and estrogen receptor-positive breast cancers. Journal of the National Cancer Institute 2011103 562-570. (doi:10.1093/jnci/djr031)

98 James RE, Lukanova A, Dossus L, Becker S, Rinaldi S, Tjonneland A, Olsen A, Overvad K, Mesrine S, Engel P et al. Postmenopausal serum sex steroids and risk of hormone receptor-positive and -negative breast cancer: a nested case-control study. Cancer Prevention Research 20114 1626-1635. (doi:10.1158/1940-6207.CAPR-11-0090)

99 Notelovitz M. Overview of bone mineral density in postmenopausal women. Journal of Reproductive Medicine 200247 71-81.

100 Khosla S, Riggs BL, Robb RA, Camp JJ, Achenbach SJ, Oberg AL, Rouleau PA \& Melton LJ. Relationship of volumetric bone density and structural parameters at different skeletal sites to sex steroid levels in women. Journal of Clinical Endocrinology and Metabolism 200590 5096-5103. (doi:10.1210/jc.2005-0396)

101 van Geel TA, Geusens PP, Winkens B, Sels JP \& Dinant GJ. Measures of bioavailable serum testosterone and estradiol and their relationships with muscle mass, muscle strength and bone mineral density in postmenopausal women: a cross-sectional study. European Journal of Endocrinology 2009160 681-687. (doi:10.1530/EJE-08-0702)

102 Davidson BJ, Ross RK, Paganini-Hill A, Hammond GD, Siiteri PK \& Judd HL. Total and free estrogens and androgens in postmenopausal women with hip fractures. Journal of Clinical Endocrinology and Metabolism 198254 115-120. (doi:10.1210/jcem-54-1-115)

103 Cummings SR, Browner WS, Bauer D, Stone K, Ensrud K, Jamal S \& Ettinger B. Endogenous hormones and the risk of hip and vertebral fractures among older women. Study of Osteoporotic Fractures Research Group. New England Journal of Medicine 1998339 733-738. (doi:10.1056/NEJM199809103391104)

104 Vanderschueren D, Vandenput L, Boonen S, Lindberg MK, Bouillon R \& Ohlsson C. Androgens and bone. Endocrine Reviews 200425 389-425. (doi:10.1210/er.2003-0003)

105 Schmidt J, Dahlgren E, Brannstrom M \& Landin-Wilhelmsen K. Body composition, bone mineral density and fractures in late postmenopausal women with polycystic ovary syndrome - a long-term follow-up study. Clinical Endocrinology 201277 207-214. (doi:10.1111/j.1365-2265.2012.04378.x)

106 Cameron DR \& Braunstein GD. Androgen replacement therapy in women. Fertility and Sterility 200482 273-289. (doi:10.1016/j. fertnstert.2003.11.062)

107 Rivera-Woll LM, Papalia M, Davis SR \& Burger HG. Androgen insufficiency in women: diagnostic and therapeutic implications. Human Reproduction Update 200410 421-432. (doi:10.1093/humupd/dmh037)

108 Morsink LF, Vogelzangs N, Nicklas BJ, Beekman AT, Satterfield S, Rubin SM, Yaffe K, Simonsick E, Newman AB, Kritchevsky SB et al. Associations between sex steroid hormone levels and depressive symptoms in elderly men and women: results from the Health $\mathrm{ABC}$ study. Psychoneuroendocrinology 200732 874-883. (doi:10.1016/ j.psyneuen.2007.06.009)

109 Yasui T, Matsui S, Tani A, Kunimi K, Yamamoto S \& Irahara M. Androgen in postmenopausal women. Journal of Medical Investigation 201259 12-27. (doi:10.2152/jmi.59.12)

110 Davis SR, Goldstat R, Papalia MA, Shah S, Kulkarni J, Donath S \& Bell RJ. Effects of aromatase inhibition on sexual function and well-being in postmenopausal women treated with testosterone: a randomized, placebo-controlled trial. Menopause 200613 37-45. (doi:10.1097/01.gme.0000168061.32917.83)

Received 8 June 2014

Revised version received 17 August 2014

Accepted 15 September 2014 